OPEN ACCESS

Edited by:

Martin G. Klotz,

Queens College, City University

of New York, USA

Reviewed by:

Susana Rodriguez-Couto,

Ikerbasque, Spain

Gerardo Díaz-Godínez,

Autonomous University of Tlaxcala,

Mexico

*Correspondence:

Hamilton Cabral

hamilton@fcfrp.usp.br

Specialty section:

This article was submitted to

Fungi and Their Interactions,

a section of the journal

Frontiers in Microbiology

Received: 29 August 2016 Accepted: 19 December 2016

Published: 09 January 2017

Citation:

Hamin Neto YAA, de Oliveira LCG,

de Oliveira JR, Juliano MA,

Juliano L, Arantes EC and Cabral H

(2017) Analysis of the Specificity and Biochemical Characterization of Metalloproteases Isolated from

Eupenicillium javanicum Using

Fluorescence Resonance Energy

Transfer Peptides.

Front. Microbiol. 7:2141.

doi: 10.3389/fmicb.2016.02141

\section{Analysis of the Specificity and Biochemical Characterization of Metalloproteases Isolated from Eupenicillium javanicum Using Fluorescence Resonance Energy Transfer Peptides}

Youssef A. A. Hamin Neto', Lilian C. G. de Oliveira², Juliana R. de Oliveira², Maria A. Juliano ${ }^{2}$, Luiz Juliano ${ }^{2}$, Eliane C. Arantes ${ }^{3}$ and Hamilton Cabral ${ }^{\text {* }}$

\footnotetext{
1 Department of Pharmaceutical Sciences, School of Pharmaceutical Sciences of Ribeirao Preto, University of São Paulo, Ribeirão Preto, Brazil, ${ }^{2}$ Department of Biophysics, Paulista Medical School, Federal University of São Paulo, São Paulo, Brazil, ${ }^{3}$ Department of Physics and Chemistry, School of Pharmaceutical Sciences of Ribeirao Preto, University of São Paulo, Ribeirão Preto, Brazil
}

Enzymes have important features that may facilitate their application in industrial processes and have been used as alternatives to chemical catalysts. In particular, proteases can be isolated from microorganisms, which provide important sources of advantageous enzymes for industrial processes. For example, Eupenicillium javanicum is a filamentous fungus that has been shown to express industrially applicable enzymes and chemical components, such as antifungal compounds. The biotechnological potential of $E$. javanicum and proteases made us search a novel protease from this microorganism. The macromolecule was isolated, the main biochemical properties was evaluated, and the specificity of the protease subsites was determined. The protease was produced under solid-state bioprocess with wheat bran and isolated by two chromatography steps with yield of $27.5 \%$ and 12.4 -fold purification. The molecular mass was estimated at $30 \mathrm{kDa}$. The $\mathrm{N}$-terminal sequence of the first 20 amino acid residues was AVGAGYNASVALALEKALNN. The enzyme presented higher proteolytic activity at $\mathrm{pH} 6.0$ and $60^{\circ} \mathrm{C}$. The protease is stable at wide range of $\mathrm{pH}$ values and temperatures and in the presence of surfactants. The "primed" side of the catalytic site showed the highest catalytic efficiency of the enzyme isolated from $E$. javanicum. The $\mathrm{S}_{1}{ }_{1}$ subsite is responsible for catalyzing the protease reaction with substrates with tyrosine in $\mathrm{P}^{\prime}{ }_{1}$. These findings provide important insights into the biochemical characterization of a highly active protease from $E$. javanicum and may facilitate the development of industrial processes involving this protease.

Keywords: biochemical characterization, fluorescence resonance energy transfer peptides, microbial enzyme, protease, solid-state fermentation 


\section{INTRODUCTION}

Enzymes present some advantages when compared with chemical catalysts. These macromolecules are able to catalyze a variety of chemical reactions, industrial processes have been shifting to the application of enzymes rather than chemicals as catalysts (Sarrouh et al., 2012). In addition, enzymes have several advantages over chemical catalysts, such as mild reaction conditions, the lack of requirement for protection of substrate functional groups, long half-lives, high stereo selectivity, and the ability to be genetically modified to improve stability, substrate specificity, and specific activity (Adrio and Demain, 2014). The key properties of enzymes, including stable activity over a range of temperatures and $\mathrm{pH}$ values and broad catalytic specificity, can be exploited in various industries and processes, such as the food, laundry, detergent, leather, pharmaceutical, and silk industries; for recovery of silver from $\mathrm{x}$-ray film; and for waste management (Nigam, 2013; Hmidet et al., 2015).

Proteases are hydrolytic enzymes that have been used in industrial processes for decades. Microorganisms under bioprocesses can act as sources of various proteases to improve the protease production and activity owing to their rapid growth and potential for genetic modification, thereby allowing scientists to enhance the features of proteases for applications in industrial processes (Souza et al., 2015).

The solid-state bioprocess present potential applications in the production of enzymes and other industrial products. It has been defined as bioprocess in the absence or near-absence of free water, with enough moisture to support the growth and metabolic activity of the microorganism. Other characteristic is the use of low-cost agro-industrial residues, it makes the solidstate fermentation attractive financially and sustainably (Thomas et al., 2013).

Among these microbial sources, the filamentous fungus Eupenicillium javanicum has been shown to produce different products with industrial interests, such as antifungal compounds (Nakadate et al., 2007, 2008), endoglucanase, $\beta$-glucosidase, pectinase, xylanase (Tao et al., 2011), and a protease stable to spray dryer process (Hamin Neto et al., 2014).

Therefore, in this study, we aimed to isolate a protease produced in E. javanicum during solid-state fermentation, evaluate the main biochemical properties of this protease, and determine the specificity of its subsites.

\section{MATERIALS AND METHODS}

\section{Isolation, Identification, and Maintenance of $E$. javanicum}

The fungus E. javanicum was isolated from silage and belongs to a collection of microorganisms at the Enzyme Technology Laboratory under the supervision of Dr. Hamilton Cabral (Faculdade de Ciências Farmacêuticas de Ribeirão Preto, Universidade de São Paulo). The fungus could be maintained in Sabouraud medium at $4^{\circ} \mathrm{C}$ for up to 1 month.

\section{Inoculum Preparation}

Eupenicillium javanicum was grown in 250-mL Erlenmeyer flasks with $30 \mathrm{~mL}$ Sabouraud culture medium. The inoculum was maintained for 7 days at $30^{\circ} \mathrm{C}$, and the mycelial surface was then scraped in presence of $20 \mathrm{~mL}$ of saline solution composed by $0.1 \%[\mathrm{w} / \mathrm{v}]\left(\mathrm{NH}_{4}\right)_{2} \mathrm{SO}_{4}+0.1 \%[\mathrm{w} / \mathrm{v}] \mathrm{NH}_{4} \mathrm{NO}_{3}+0.1 \%$ $[\mathrm{w} / \mathrm{v}] \mathrm{MgSO}_{4} \cdot 7 \mathrm{H}_{2} \mathrm{O}$.

\section{Solid-State Bioprocess (SSB)}

The protease were produced by E. javanicum under SSB in 250$\mathrm{mL}$ erlenmeyer flasks containing $5 \mathrm{~g}$ wheat bran and $9.0 \mathrm{~mL}$ saline solution. The medium was sterilized by autoclaving at $121^{\circ} \mathrm{C}$ for $40 \mathrm{~min}$. One milliliter of the inoculum was added before incubation at $30^{\circ} \mathrm{C}$. After $140 \mathrm{~h}$, the bioprocess was stopped, and $40 \mathrm{~mL}$ distilled water $\left(4^{\circ} \mathrm{C}\right)$ was added to each flask for extracellular enzyme solubilization. This process was aided by maceration with a plastic rod, and the flasks were then agitated in a shaker at $200 \mathrm{rpm}$ for $30 \mathrm{~min}$ at $4^{\circ} \mathrm{C}$. The material was filtered and centrifuged at $5,000 \times g$ for $20 \mathrm{~min}$ at $4^{\circ} \mathrm{C}$. The supernatant was collected as the enzymatic extract (Hamin Neto et al., 2013).

\section{Evaluation of Proteolytic Activity with Casein as Substrate}

Proteolytic activity was evaluated using casein substrate according to the protocol described by Sarath et al. (1989), with some modifications. One milliliter of $1 \%(\mathrm{w} / \mathrm{v})$ casein in $50 \mathrm{mM}$ monobasic sodium phosphate buffer ( $\mathrm{pH}$ 6.5) was combined with $100 \mu \mathrm{L}$ of $50 \mathrm{mM}$ monobasic sodium phosphate buffer ( $\mathrm{pH}$ 6.5) and $100 \mu \mathrm{L}$ enzymatic extract. The reaction mixture was incubated for $60 \mathrm{~min}$ at $40^{\circ} \mathrm{C}$, and $600 \mu \mathrm{L}$ of $10 \%$ $(\mathrm{w} / \mathrm{v})$ trichloroacetic acid (TCA) was then added to stop the reaction. The reaction tubes were centrifuged at $10000 \times g$ for $10 \mathrm{~min}$ at $30^{\circ} \mathrm{C}$. The absorbance of the supernatants was then measured relative to the blank controls in cuvettes at $280 \mathrm{~nm}$ in a spectrophotometer (GENESYS 10S UV Vis; Thermo Fischer Scientific Inc.). One unit of activity was defined as the amount of the enzyme required to cause an increase of 0.001 of absorbance at $280 \mathrm{~nm}$ (Gupta et al., 2002).

\section{Enzyme Purification by Chromatography}

The enzymatic extract was subjected to gel filtration with a column $(100 \mathrm{~cm} \times 4 \mathrm{~cm})$ using Sephadex G-50 resin. The equilibration buffer was $50 \mathrm{mM}$ acetate $(\mathrm{pH} 5.0)$ with $50 \mathrm{mM}$ $\mathrm{NaCl}$, and the elution flow rate was $0.62 \mathrm{~mL} / \mathrm{min}$, regulated by a peristaltic pump (GE-Healthcare). The resin was equilibrated with five column volumes $(\mathrm{CV})$, and $5 \mathrm{~mL}$ of sample was then applied. The gradient was isocratic, and $5-\mathrm{mL}$ fractions were collected.

Enzyme fractions were subjected to dialysis with a $14-\mathrm{kDa}$ membrane and $50 \mathrm{mM}$ Tris- $\mathrm{HCl}$ buffer $(\mathrm{pH} 8.0)$ for $24 \mathrm{~h}$ at $4^{\circ} \mathrm{C}$. The dialyzed samples $(15 \mathrm{~mL})$ were applied to Tricorn columns with $6 \mathrm{~mL}$ Resource-Q resin (anionic properties), preequilibrated with five $\mathrm{CV}$ of $50 \mathrm{mM}$ Tris- $\mathrm{HCl}$ buffer ( $\mathrm{pH} 8.0$ ). After application, the resin was washed with the same buffer (two $\mathrm{CV}$ ), and a linear salt gradient was then started from 0 to $500 \mathrm{mM}$ $\mathrm{NaCl}$ using $20 \mathrm{CV}$ of buffer at an elution flow rate of $2 \mathrm{~mL} / \mathrm{min}$. 
One-milliliter fractions were collected. The process was carried out using an ÄKTA Purifier chromatograph (GE-Healthcare) at $25^{\circ} \mathrm{C}$.

Proteolytic activity assays and analysis by determination of absorbance at $280 \mathrm{~nm}$ were carried out to determine the enzymatic and protein profiles, respectively, and a NanoVue UV/Visible Spectrophotometer (GE-Healthcare) was used to quantify total protein at $280 \mathrm{~nm}$, after each chromatographic process.

\section{Evaluation of the Purity and Molecular Mass of the Protease}

The enzyme fraction purity was evaluated by denaturing polyacrylamide gel electrophoresis (SDS-PAGE) using $12 \%$ gels (Laemmli, 1970) stained with silver nitrate (See and Jackowski, 1989). The size of the protease was estimated using Image Lab software version 3.0.

\section{Determination of the N-Terminal Sequence of the Protease}

The N-terminal sequence was determined by cleaving the $\mathrm{N}$-terminal amino acids of proteins and peptides using Edman degradation on a Protein Sequencer PPSQ-33A instrument (Shimadzu Corporation). The PTH-amino acids were separated by high-performance liquid chromatography (HPLC), identified, and analyzed by comparing retention times and UV absorption with a previously quantified standard (Graminho et al., 2013).

\section{Peptide Substrate Synthesis and Cleavage Site Determination}

Fluorescence resonance energy transfer (FRET) peptides were synthesized in an automatic solid-phase peptide synthesizer (Model PSSM-8; Shimadzu Corporation; Hirata et al., 1995) and purified using semi preparative HPLC. Molecular mass determination was carried out using matrix-assisted laser desorption ionization time-of-flight (MALDI-TOF) mass spectrometry with a Microflex LT mass spectrometer (Bruker-Daltonics). Peptide solutions were prepared by resuspending the substrate in dimethyl sulfoxide (DMSO), and their concentrations were determined with a molar extinction coefficient at $365 \mathrm{~nm}$ of $17,300 \mathrm{M}^{-1} \mathrm{~cm}^{-1}$ in a spectrophotometer (Hirata et al., 1995). The scissile bonds of hydrolyzed peptides were identified by the isolation of fragments using analytical HPLC followed by determination of their molecular mass with an LCMS-2020 equipped with an electrospray ionization (ESI) probe (Shimadzu Corporation; Oliveira et al., 2015).

\section{Biochemical Characterization}

Functional biochemical characterization of the purified protease was conducted using FRET peptides. In these peptides, an ortho-aminobenzoic acid (Abz), responsible for the molecular fluorescence emission, was conjugated to the N-terminal amino group, and (2,4-dinitrophenyl)ethylenediamine (EDDnp), a quencher of fluorescence, was conjugated to the C-terminal carboxyl group (Chagas et al., 1991). A fluorescence signal was observed upon cleavage of any peptide bond within the amino acid sequence.

\section{Test Conditions for the Enzymatic Reaction during Functional Biochemical Characterization Using FRET Substrates}

The enzymatic reaction was carried out using a Lumina fluorescence spectrometer (Thermo Fischer Scientific Inc.) coupled with a Peltier system 4-Position Cell Holder Fluorescence device to control the agitation speed and assay temperature. Reactions with Abz-KLRSSKQ-EDDnp substrate were carried out in a quartz cuvette with an optical path length of $10 \mathrm{~mm}$. The wavelengths were set to $\lambda$ ex: $320 \mathrm{~nm}$ and $\lambda$ em: $420 \mathrm{~nm}$. Data were collected and analyzed using Luminous software version 3.0.

\section{Effects of $\mathrm{pH}$ and Temperature}

The optimum $\mathrm{pH}$ was determined by evaluating different $\mathrm{pH}$ values from 4.0 to 10.5 with intervals of $0.5 \mathrm{pH}$ units at $40^{\circ} \mathrm{C}$. The buffers used in this analysis were acetate ( $\mathrm{pH} 4.0-5.0)$, MES ( $\mathrm{pH}$ 5.5-6.0), HEPES ( $\mathrm{pH} 7.0-8.0$ ), BICINE ( $\mathrm{pH} 8.5-9.0$ ), and CAPS ( $\mathrm{pH}$ 9.5-10.5). After determining the optimum $\mathrm{pH}$, the optimum temperature was determined from 30 to $75^{\circ} \mathrm{C}$, with intervals of $5^{\circ} \mathrm{C}$, at $\mathrm{pH}$ 6.0. The statistical analysis was performed with oneway ANOVA (analysis of variance) and post hoc Tukey, results with $p<0.05$ were considered significant.

The stability of the enzyme at different $\mathrm{pH}$ values was evaluated by incubating the pure enzyme at $25^{\circ} \mathrm{C}$ for $60 \mathrm{~min}$ at various $\mathrm{pH}$ values (4.0-10.5), with intervals of $0.5 \mathrm{pH}$ units, followed by reaction at $\mathrm{pH} 6.0$ and $45^{\circ} \mathrm{C}$. The buffers used in this analysis were acetate ( $\mathrm{pH} 4.5-5.0)$, MES ( $\mathrm{pH}$ 5.5-6.0), HEPES ( $\mathrm{pH} 7.0-8.0$ ), BICINE ( $\mathrm{pH} 8.5-9.0$ ), and CAPS ( $\mathrm{pH} 9.5-10.0)$.

Thermal stability at different temperatures $\left(30-60^{\circ} \mathrm{C}\right)$ and for different incubation times $(5,15,30$, and $60 \mathrm{~min})$ was evaluated by proteases pre-incubation, followed by reaction at $\mathrm{pH} 6.0$ and $45^{\circ} \mathrm{C}$.

\section{Effects of lons and Inhibitors}

The effects of ions on proteolytic activity were analyzed using $\mathrm{NaCl}, \mathrm{CoCl}_{2}, \mathrm{CuCl}_{2}, \mathrm{CaCl}_{2}, \mathrm{MgCl}_{2}, \mathrm{BaCl}_{2}$, and $\mathrm{AlCl}_{3}$. The inhibitors tested in this analysis were phenylmethylsulfonyl fluoride (PMSF), ethylenediaminetetraacetic acid (EDTA), iodoacetic acid (IAA), and pepstatin (100 mM stock solutions) according to the protocol described by Dunn (1989). Pure enzyme solution and inhibitors or ions were added to each reaction tube at a final concentration of $10 \mathrm{mM}$ for the inhibitors and ions. The effects of these inhibitors and ions were then analyzed by reaction for $5 \mathrm{~min}$ at $45^{\circ} \mathrm{C}$, followed by further incubation at $\mathrm{pH} 6.0$ at $45^{\circ} \mathrm{C}$. The statistical analysis was performed with one-way ANOVA (analysis of variance) and post hoc Tukey, results with $p<0.05$ were considered significant.

\section{Effects of Surfactants}

The effects of surfactants on proteolytic activity were analyzed using sodium dodecyl sulfate (SDS), cetyltrimethylammonium bromide (CTAB), TritonX-100, and Tween 20 solutions. Pure enzyme solution and surfactants were added to each reaction at 
final concentrations of $0.1,0.2,0.5$, or $1.0 \%$ for all surfactants except SDS, which was analyzed at $0.02,0.04,0.06,0.08$, and $0.1 \%$. The effects of these surfactants were then analyzed by reaction for $5 \mathrm{~min}$ at $45^{\circ} \mathrm{C}$, followed by further incubation at $\mathrm{pH} 6.0$ at $45^{\circ} \mathrm{C}$.

\section{Effects of Urea, Guanidine, and Dithiothreitol (DTT)}

Pure enzyme solution and test agents were added to reaction tubes at final concentrations of $10,25,50,100$, or $150 \mathrm{mM}$ for urea, guanidine, or DTT. The effects of these three components were then analyzed by reaction for $5 \mathrm{~min}$ at $45^{\circ} \mathrm{C}$, followed by further incubation at $\mathrm{pH} 6.0$ at $45^{\circ} \mathrm{C}$.

\section{Determination of the Molar Concentration of the Purified Enzyme}

The molar concentration of the enzyme was determined by active site titration with the inhibitor phosphoramidon, as described by Klemencic et al. (2000) with modifications. Samples were analyzed in a Lumina fluorescence spectrometer (Thermo Fischer Scientific Inc.) using the substrate Abz-KLRSSKQ-EDDnp at $\mathrm{pH}$ 6.0 and $45^{\circ} \mathrm{C}$. The wavelengths of fluorescence were adjusted to $\lambda$ ex: $320 \mathrm{~nm}$ and $\lambda$ em: $420 \mathrm{~nm}$.

\section{Kinetic Experiments with Synthetic Substrate}

Kinetic assays were performed to study the effects of changes in the positions of the amino acids in the substrate and to determine the substrate preference of the anchoring enzyme according to the distribution of amino acids in the peptide sequence. These variations were defined as $\mathrm{P}_{3}, \mathrm{P}_{2}, \mathrm{P}_{1}, \mathrm{P}^{\prime}{ }_{1}, \mathrm{P}^{\prime}{ }_{2}$, and $\mathrm{P}^{\prime}{ }_{3}$, represented as follows in enzymes: $S_{3}, S_{2}, S_{1}, S_{1}^{\prime}, S_{2}^{\prime}$, and $S_{3}^{\prime}$ (Berger and Schechter, 1970). The kinetic parameters of substrate (AbzKLXSSKQ-EDDnp) hydrolysis were evaluated with $\mathrm{X}$ variations in the indicated positions $\left(\mathrm{P}_{3}, \mathrm{P}_{2}, \mathrm{P}_{1}, \mathrm{P}_{1}^{\prime}, \mathrm{P}_{2}^{\prime}\right.$, and $\left.\mathrm{P}_{3}^{\prime}\right)$.

Enzymatic kinetic data were obtained by addition the substrate to the reaction cuvette with increasing concentrations. The experiments were performed at $\mathrm{pH} 6.0$ and $45^{\circ} \mathrm{C}$, and absorbance was measured using a Lumina fluorescence spectrometer (Thermo Scientific), with control of agitation and reaction temperature using a Fluorescence Peltier 4-Position Cell Holder (Thermo Fischer Scientific Inc.). The wavelengths were set to $\lambda$ ex: $320 \mathrm{~nm}$ and $\lambda \mathrm{em}: 420 \mathrm{~nm}$.

The kinetic parameters were obtained from the MichaelisMenten equation calculated by non-linear regression of data from hydrolysis of the substrate using Grafit version 5.0. We analyzed the $K_{\mathrm{M}}, k_{\text {cat }}$, and $k_{\text {cat }} / K_{\mathrm{M}}$ to determine the preference of the enzyme for different substrates.

\section{RESULTS}

\section{Enzyme Purification by Chromatography}

The fungus E. javanicum produced a protease that could be reproducibly purified using the steps described in Table 1. A final yield of $27.5 \%$ was obtained, with 12.4 -fold purification. The elution profile from Sephadex G-50 resin chromatography showed two protein peaks, and peak II (fractions 70-90) exhibited proteolytic activity (Figure 1). These fractions were then subjected to anion exchange chromatography (Resource-Q resin), and the elution profile showed four protein peaks. Peaks II (fractions 61-63) and III (fractions 65-67) showed enzymatic activity (Figure 2). Peak III was used as the purified enzyme in subsequent steps as this peak showed higher specific activity, fold purification, and yield than peak II. Figure 3 shows the purity and estimated molecular weight of the enzyme (30 kDa).

\section{Determination of the $\mathrm{N}$-Terminal Sequence}

The N-terminal sequence of the first 20 amino acid residues of the protease from E. javanicum was AVGAGYNASVALALEKALNN. The N-terminal sequence was similar (query cover: $75 \%$ and identity: 73\%) with other proteases secreted from the filamentous fungi Colletotrichum salicis (KXH28323.1), C. fioriniae PJ7 (XP 007596472.1), C. gloeosporioides Nara gc5 (XP 007281997.1), and C. Simmondsii (KXH42882.1), as shown in Figure 4.

\section{Biochemical Characterization}

\section{Effects of $\mathrm{pH}$ and Temperature on Enzyme Activity}

For biochemical characterization of the enzyme, we first analyzed the optimum $\mathrm{pH}$. Interestingly, the protease showed about $75 \%$ or more residual activity from $\mathrm{pH} 5.5-8.0$, with $97 \%$ or more between $\mathrm{pH} 5.5$ and 6.5 , the optima $\mathrm{pH}$ was at 6.0 , with The optimum temperature was $60^{\circ} \mathrm{C}$, with statistical difference compared with all $\mathrm{pH}$ values except at 6.5, $p<0.05$ (Figure 5). Proteolytic activity was lower at more extreme $\mathrm{pH}$ values. Enzymatic assays with incubation at different temperatures showed an increase from 30 to $60^{\circ} \mathrm{C}$, followed by a drop in activity at temperatures over $60^{\circ} \mathrm{C}$. The enzyme maintained and $80 \%$ or more activity from 50 to $70^{\circ} \mathrm{C}$. The optimum temperature was $60^{\circ} \mathrm{C}$, with statistical difference compared with all temperatures tested, $p<0.05$ (Figure 6).

Analysis of protease stability at different $\mathrm{pH}$ values showed that the enzyme had greater stability from $\mathrm{pH} 4.5-10.0$ with maintenance of about $67 \%$ or more of it stability after $60 \mathrm{~min}$ of incubation at $25^{\circ} \mathrm{C}$ (Figure 7). The protease showed great thermal stability during a 60 -min incubation; from 30 to $55^{\circ} \mathrm{C}$, the residual activity was about $80 \%$ or more, and at $60^{\circ} \mathrm{C}$, the residual activity of the enzyme was $50 \%$ (Figure 8 ). Thus, these results suggested that the enzyme was thermostable despite being produced by a mesophilic fungus.

\section{Effects of lons and Inhibitors}

Metal ions can either positively and negatively affect protease activity. In this study, we found that $10 \mathrm{mM}$ sodium, barium, or cobalt increased proteolytic activity by 52,24 , and $24 \%$, only sodium showed statistical difference compared with control, $p<0.0001$ (Table 2), respectively, while aluminum decreased the original proteolytic activity by $16 \%$. Additionally, EDTA inhibited the proteolytic activity by about $69 \%$ with statistical difference, $p<0.0001$, whereas PMSF, IAA, and pepstatin inhibited proteolytic activity by 30,27 , and $20 \%$, respectively, (Table 3 ). These results suggested that the enzyme maybe a metalloprotease. 
TABLE 1 | Summary of the purification steps for the Eupenicillium javanicum protease, produced by a solid-state bioprocess.

\begin{tabular}{|c|c|c|c|c|c|}
\hline Steps & Total activity (U) & Total protein $(\mathrm{mg})$ & Specific activity (U/mg) & Purification (fold) & Yield (\%) \\
\hline Crude extract & 1569.6 & 16.535 & 94.9 & 1.0 & 100.0 \\
\hline Sephadex G-50 & 1302.7 & 2.480 & 525.3 & 5.5 & 83.0 \\
\hline Resource-Q peak 1 & 394.9 & 0.448 & 881.6 & 9.3 & 25.2 \\
\hline Resource-Q peak 2 & 431.9 & 0.368 & 1173.7 & 12.4 & 27.5 \\
\hline
\end{tabular}

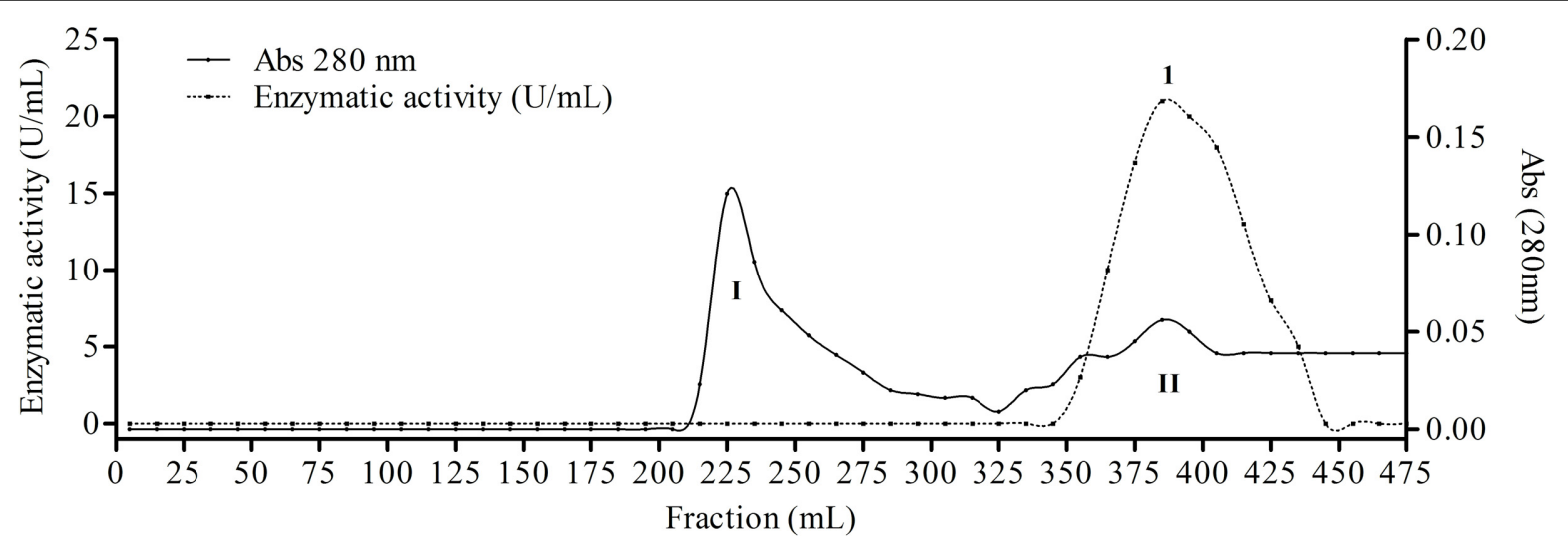

FIGURE 1 | Elution profile of proteins and protease from Eupenicillium javanicum solid-state bioprocess in chromatography of mass exclusion with Sephadex g-50 resin. The elution buffer was acetate $50 \mathrm{mM}, \mathrm{pH} 5.0$ and $50 \mathrm{mM} \mathrm{NaCl}$. The flow was maintained in $0.62 \mathrm{~mL} / \mathrm{min}$ and fractions of $5 \mathrm{~mL}$.

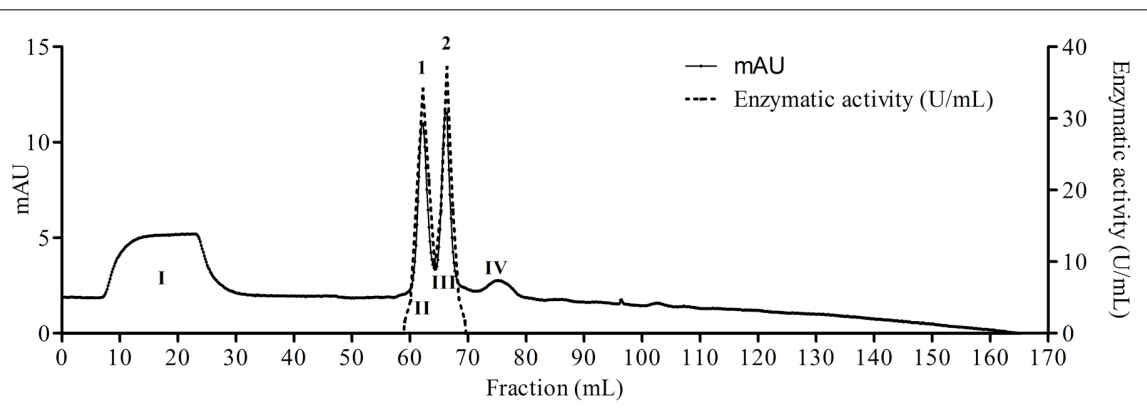

FIGURE 2 | Elution profile of proteins and protease from E. javanicum solid-state bioprocess in chromatography of anion exchange with Resource-Q resin. The elution buffer was Tris- $\mathrm{HCl} 50 \mathrm{mM}, \mathrm{pH} 8.0$ and gradient from 0 to $500 \mathrm{mM}$ of $\mathrm{NaCl}$. The flow was maintained in $2 \mathrm{~mL} / \mathrm{min}$ and fractions of $1 \mathrm{~mL}$.

\section{Effects of Surfactants}

Figure 9 shows the residual activity of the protease isolated from E. javanicum in the presence of surfactants. The enzyme was stable at different concentrations of Triton X-100 and Tween 20; at the maximum concentration tested (1\%), the protease maintained about 68 and $58 \%$ of its activity, respectively. Increases in CTAB and SDS concentrations decreased protease activity; specifically, the protease retained about $28 \%$ activity in the presence of $0.1 \%$ CTAB and about $30 \%$ activity in the presence of $0.02 \%$ SDS.

\section{Effects of Urea, Guanidine, and DTT}

As shown in Figure 10, urea, guanidine, and DTT also affected proteolytic activity. Increased concentrations of DTT resulted in decreased enzymatic activity, maintaining about $40 \%$ of enzyme activity when the concentration of DTT was $100 \mathrm{mM}$. In the presence of $150 \mathrm{mM}$ urea, the enzyme maintained about $54 \%$ of its original activity. Interestingly, guanidine had a greater effect, reducing the activity of the enzyme by only $10 \%$ when used at a concentration of $150 \mathrm{mM}$.

\section{Kinetic Experiments with a Synthetic Substrate}

Table 4 shows the catalytic specificity of the protease for $S_{1}, S_{2}$, and $S_{3}$ subsites in relation to replacement of amino acids at $\mathrm{P}_{1}, \mathrm{P}_{2}$, and $\mathrm{P}_{3}$ positions using a FRET peptide series based on the sequence Abz-KLRSSKQ-EDDnp (considering the cleavage between Arg and Ser). The position $\mathrm{P}_{1}$ provided higher catalytic efficiency with arginine, phenylalanine, and methionine $\left(2,146,2,043\right.$, and $1,843 \mathrm{mM}^{-1} \cdot \mathrm{seg}^{-1}$, respectively). Moreover, the protease exhibited higher affinity when glutamine was in this amino acid position, with a $K_{\mathrm{M}}$ of $0.004 \mathrm{mM}$. 


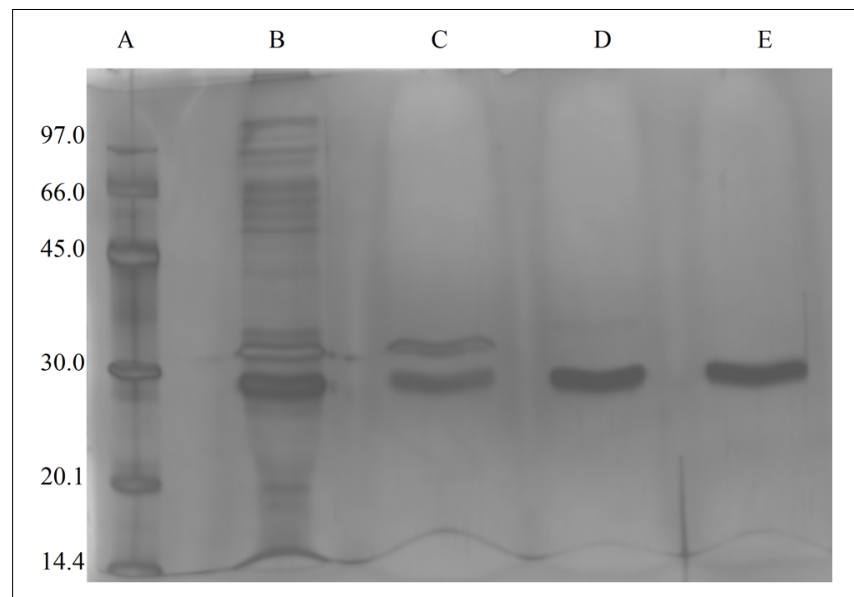

FIGURE 3 | Image of SDS-PAGE gels (12\%) stained with silver nitrate, the sample were from Eupenicillium javanicum solid-state bioprocess.

(A) Molecular weight markers, (B) crude extract, (C) g-50 fraction,

(D) Resource-Q peak I, and (E) Resource-Q peak II.
Eupenicillium javanicum

Colletotrichum salicis

Colletotrichum fioriniae PJ7

Colletotrichum gloeosporioides Nara gc5

Colletotrichum simmondsii
AVGAGYNASVALALEKALNN YNASIALAPERALQN YNASVALPPERALHN YNASVALPPERALQN YNASVALPPERALQN
FIGURE 4 | N-terminal amino acid sequence of the protease isolated from $E$. javanicum solid-state bioprocess and comparisons with other proteases from Colletotrichum salicis, C. fioriniae PJ7,

C. gloeosporioides Nara gc5, and C. simmondsii.

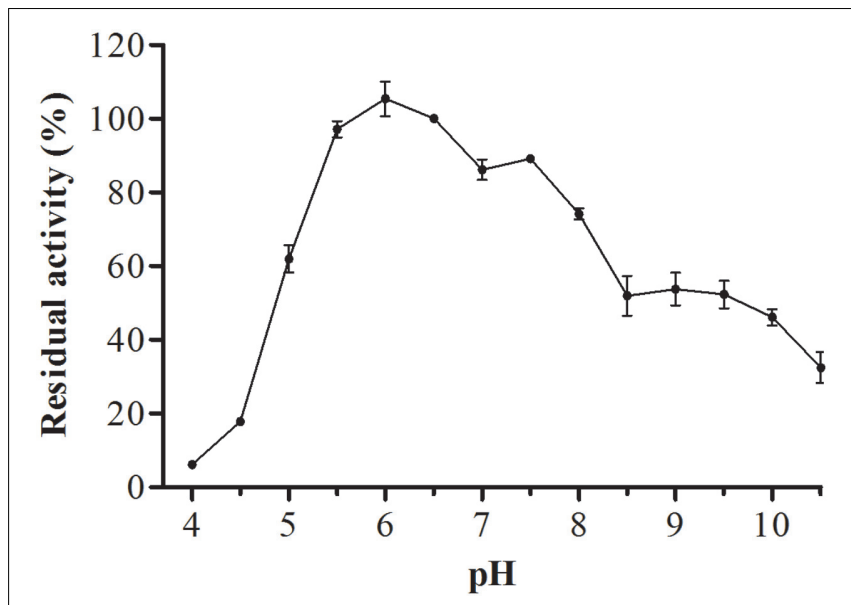

FIGURE 5 | Optimum proteolytic activity at different $\mathrm{pH}$ values (4.0-10.5), the reaction was conducted at $40^{\circ} \mathrm{C}$, using Abz-KLRSSKQ-EDDnp as substrate in fluorescence spectrometer.

Most of the substrates were cleaved between $\mathrm{P}^{\prime}{ }_{1}$ and $\mathrm{P}_{2}^{\prime}$; in the presence of arginine and glutamine, the substrate was cleaved as follows: $\mathrm{P}_{1} \downarrow \mathrm{P}^{\prime}{ }_{1} \downarrow \mathrm{P}_{2}^{\prime}$. The best values for the $\mathrm{S}_{2}$ subsite were with substrates containing valine and arginine at the $\mathrm{P}_{2}$ substrate position; the catalytic efficiencies were 2,141 and $1,850 \mathrm{mM}^{-1} \cdot \mathrm{seg}^{-1}$. The enzyme showed high affinity for

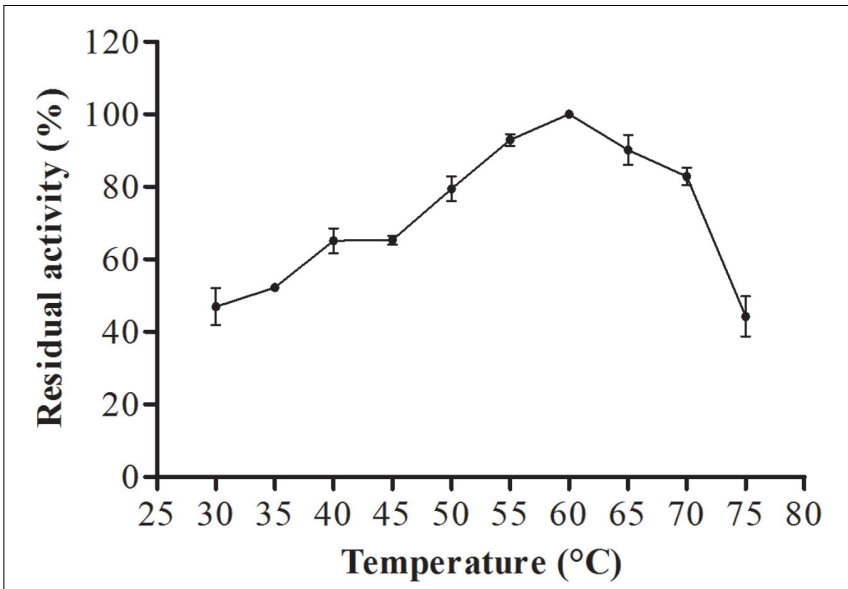

FIGURE 6 | Optimum proteolytic activity at different temperatures $\left(30-75^{\circ} \mathrm{C}\right)$ the reaction was conducted at $\mathrm{pH} 6.0$, using

Abz-KLRSSKQ-EDDnp as substrate in fluorescence spectrometer.

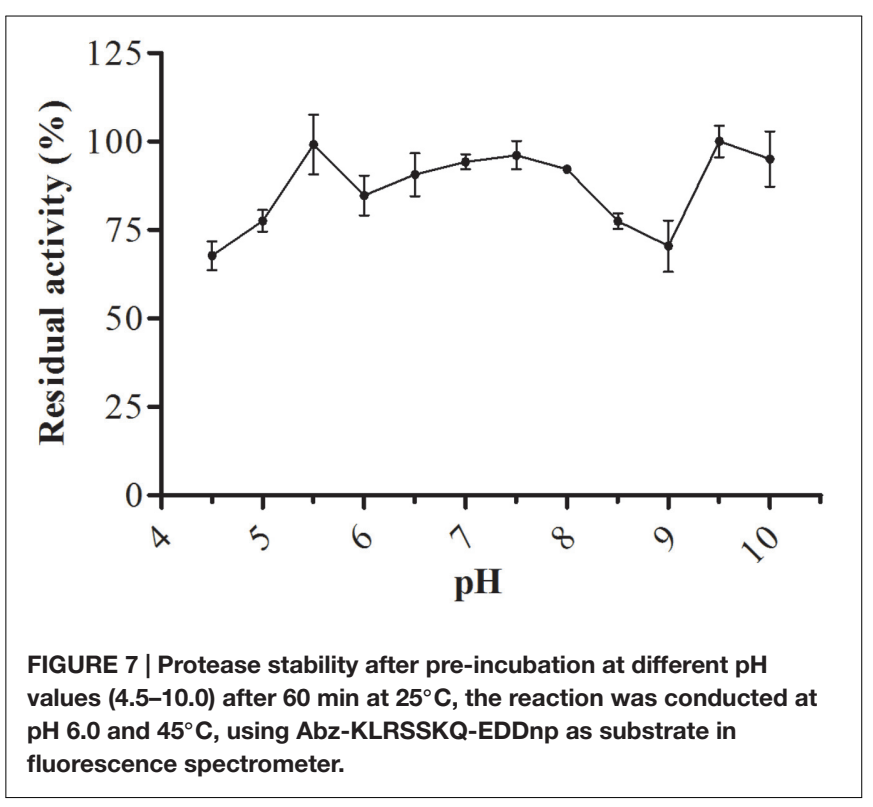

phenylalanine, with a $K_{\mathrm{M}}$ of $0.012 \mathrm{mM}$. The substrates were cleaved between $\mathrm{P}_{1}^{\prime}$ and $\mathrm{P}_{2}^{\prime}$, except for phenylalanine and tyrosine, which were cleaved as follows: $\mathrm{P}_{1} \downarrow \mathrm{P}^{\prime}{ }_{1} \downarrow \mathrm{P}^{\prime}{ }_{2}$. The kinetic parameters of the protease at $\mathrm{S}_{3}$ showed that the presence of hydrophobic amino acids, such as valine, isoleucine, and alanine, led to the highest catalytic efficiencies $(4,539,3,886$, and 2,836 $\mathrm{mM}^{-1} \cdot \mathrm{seg}^{-1}$, respectively). The enzyme showed high affinity for valine, with a $K_{\mathrm{M}}$ of $0.010 \mathrm{mM}$. All substrates were cleaved at two positions, $\mathrm{P}_{1} \downarrow \mathrm{P}^{\prime}{ }_{1} \downarrow \mathrm{P}^{\prime}{ }_{2}$, except in the presence of serine, where the cleavage pattern was $\mathrm{P}^{\prime}{ }_{1} \downarrow \mathrm{P}^{\prime}{ }_{2}$; that of arginine was not determined.

Table 5 shows values of the protease kinetic parameters at $\mathrm{S}_{1}^{\prime}, \mathrm{S}_{2}^{\prime}$, and $\mathrm{S}_{3}^{\prime}$ subsites related to substrate substitution at $\mathrm{P}_{1}^{\prime}, \mathrm{P}_{2}^{\prime}$, and $\mathrm{P}_{3}^{\prime}$ positions. Analysis of the $\mathrm{S}_{1}^{\prime}$ data showed that the substrate containing tyrosine was the most hydrolyzed, 


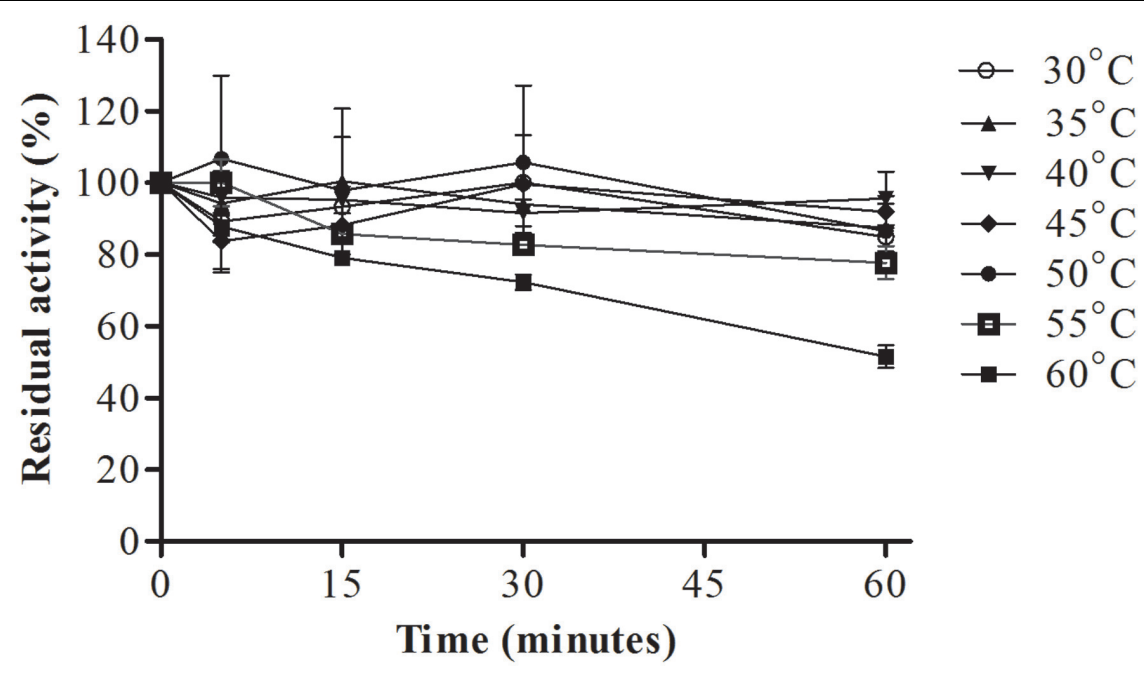

FIGURE 8 | Protease stability after pre-incubation at different temperatures $\left(30-60^{\circ} \mathrm{C}\right)$ for different times $(5,15,30$, and $60 \mathrm{~min})$, the reaction was conducted at $\mathrm{pH} 6.0$ and $45^{\circ} \mathrm{C}$, using Abz-KLRSSKQ-EDDnp as substrate in fluorescence spectrometer.

TABLE 2 | Effects of $10 \mathrm{mM}$ of different ions on the hydrolysis of Fluorescence resonance energy transfer (FRET) substrate by the purified E. javanicum protease.

\begin{tabular}{lc}
\hline Salts & Residual proteolytic activity (\%) \\
\hline Control & $100 \pm 12.74$ \\
$\mathrm{NaCl}$ & $152 \pm 10.94$ \\
$\mathrm{BaCl}_{2}$ & $124 \pm 12.21$ \\
$\mathrm{CoCl}_{2}$ & $124 \pm 3.92$ \\
$\mathrm{CuCl}_{2}$ & $98 \pm 3.43$ \\
$\mathrm{MgCl}_{2}$ & $96 \pm 2.13$ \\
$\mathrm{CaCl}_{2}$ & $94 \pm 6.32$ \\
$\mathrm{AlCl}_{3}$ & $84 \pm 12.39$
\end{tabular}

The values were presented as media \pm standard deviation.

The reaction was pre incubated for $5 \mathrm{~min}$ at $45^{\circ} \mathrm{C}$, followed by reaction at $\mathrm{pH} 6.0$ at $45^{\circ} \mathrm{C}$ with $\mathrm{Abz}-\mathrm{KLRSSKQ-EDDnp}$ substrate.

TABLE 3 | Effects of $10 \mathrm{mM}$ different inhibitors on the hydrolysis of FRET substrate by the purified $E$. javanicum protease.

\begin{tabular}{lc}
\hline Inhibitors & Residual proteolytic activity (\%) \\
\hline Control & $100 \pm 4.80$ \\
EDTA & $31 \pm 0.84$ \\
PMSF & $70 \pm 1.55$ \\
lodoacetic acid & $73 \pm 5.86$ \\
Pepstatin & $80 \pm 4.89$ \\
\hline
\end{tabular}

The values were presented as media \pm standard deviation.

The reaction was pre incubated for $5 \mathrm{~min}$ at $45^{\circ} \mathrm{C}$, followed by reaction at $\mathrm{pH} 6.0$ at $45^{\circ} \mathrm{C}$ with $\mathrm{Abz}-\mathrm{KLRSSKQ-EDDnp}$ substrate.

with a catalytic efficiency of $87,849 \mathrm{mM}^{-1} \cdot \mathrm{seg}^{-1}$, followed by arginine (catalytic efficiency: $18,914 \mathrm{mM}^{-1} \cdot \mathrm{seg}^{-1}$ ) and lysine $\left(14,876 \mathrm{mM}^{-1} \cdot \mathrm{seg}^{-1}\right)$. All substrates evaluated could be hydrolyzed by protease, particularly tyrosine, which resulted in the highest enzyme affinity $\left(K_{\mathrm{M}}: 0.007 \mathrm{mM}\right)$. The most frequently

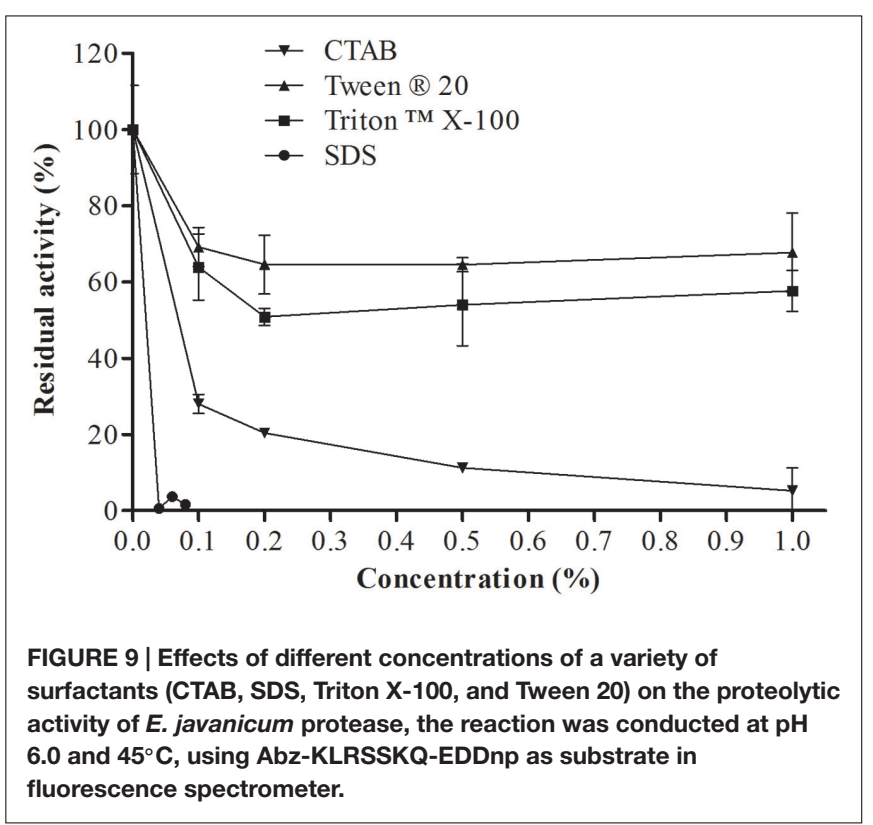

cleaved site was $\mathrm{P}_{1}^{\prime} \downarrow \mathrm{P}^{\prime}{ }_{2}$, except in the presence of valine $\left(\mathrm{P}_{2} \downarrow \mathrm{P}_{1}\right)$, lysine $\left(\mathrm{P}_{1}^{\prime}{ }_{1} \mathrm{P}^{\prime}{ }_{2} \downarrow \mathrm{P}_{3}^{\prime}\right)$, and Arg or Met $\left(\mathrm{P}_{2} \downarrow \mathrm{P}_{1} \mathrm{P}_{1}^{\prime}{ }_{1} \mathrm{P}_{2}^{\prime}\right)$. The protease kinetic parameters in isoleucine presence at $\mathrm{S}_{2}^{\prime}$ subsite provided high catalytic efficiency with $13,700 \mathrm{mM}^{-1} \cdot \mathrm{seg}^{-1}$. The affinity of the enzyme was higher in the presence of isoleucine and tyrosine, $K_{\mathrm{M}}$ 0.003. Additionally, the most frequently cleaved sites were $\mathrm{P}_{2} \downarrow \mathrm{P} 1_{\downarrow} \mathrm{P}^{\prime}{ }_{1}$ for proline and tyrosine; $\mathrm{P}_{1} \downarrow \mathrm{P}^{\prime}{ }_{1 \downarrow} \mathrm{P}^{\prime}{ }_{2}$ for alanine, arginine, glutamine, glutamic acid, and histidine; $\mathrm{P}_{2} \downarrow \mathrm{P}_{1} \downarrow \mathrm{P}_{1}^{\prime} \downarrow \mathrm{P}_{2}^{\prime}$ for glycine; and $\mathrm{P}_{2} \downarrow \mathrm{P}_{1} \downarrow \mathrm{P}^{\prime}{ }_{1} \downarrow \mathrm{P}^{\prime}{ }_{2} \downarrow \mathrm{P}^{\prime}{ }_{3}$ for histidine. The $\mathrm{S}_{3}^{\prime}$ subsite had higher catalytic efficiency in the presence of tyrosine and phenylalanine $(3,833$ and $2,085 \mathrm{mM}{ }^{-1} \cdot \mathrm{seg}^{-1}$, respectively). The cleavage was different for all substrates. 


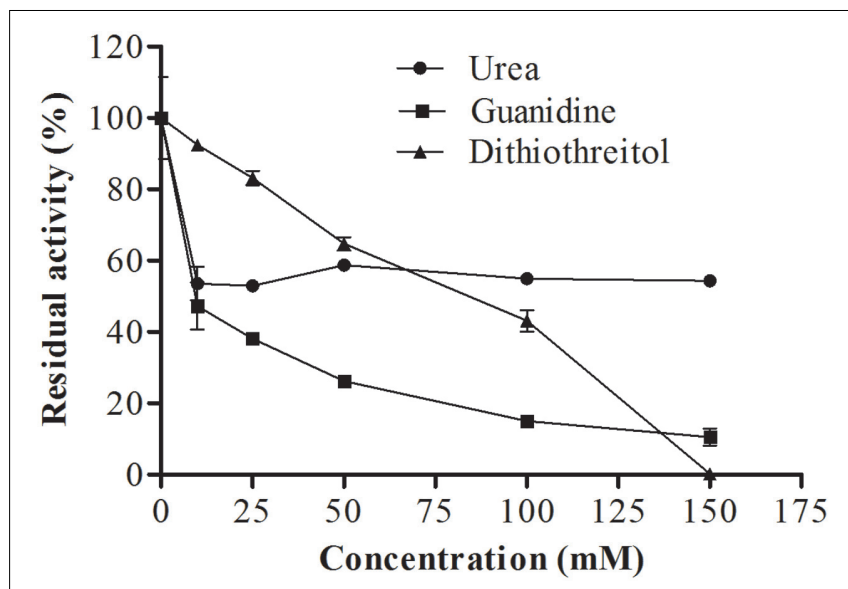

FIGURE 10 | Effects of different concentrations of dithiothreitol, guanidine, and urea on the proteolytic activity of $E$. javanicum protease, the reaction was conducted at $\mathrm{pH} 6.0$ and $45^{\circ} \mathrm{C}$, using Abz-KLRSSKQ-EDDnp as substrate in fluorescence spectrometer.

\section{DISCUSSION}

In this study, we evaluated the optimum $\mathrm{pH}$ and temperature, stability, and kinetic parameters of a protease isolated from solidstate fermentation of E. javanicum. According to the literature, the Penicillium genus has the potential to produce different proteases; for example, Penicillium waksmanii (Graminho et al., 2013), P. digitatum (Aissaoui et al., 2014), and P. italicum (Abidi et al., 2014) produce serine proteases under submerged bioprocesses, whereas $P$. waksmanii and $P$. corylophilum (Da Silva et al., 2013) also produce serine proteases under solid-state fermentation. Moreover, similar to E. javanicum, Penicillium ssp. produces metalloproteases during solid-state fermentation (El-Gendy, 2010).

\section{Enzyme Purification by Chromatography}

Purification processes can vary depending on the specific enzyme being isolated. For example, the different chromatography steps can be modified according to the stability of the enzyme in response to process conditions, influencing the recovery and purification fold, that influence directly in cost of industrial use. Previous studies have described appropriate purification parameters for enzymes from P. italicum (Abidi et al., 2014), Beauveria sp. (Shankar et al., 2011), and Trichoderma harzianum (Savitha et al., 2011). Additionally, the protease purified from submerged medium of Aspergillus oryzae KSK-3 had 182.7-fold purification, but a recovery of only $0.005 \%$ (Shirasaka et al., 2012). A metalloprotease isolated from Penicillium spp. showed lower recovery and purification than that from E. javanicum (4.93 and $3.56 \%$, respectively; El-Gendy, 2010). Therefore the purification of the metalloprotease from E. javanicum presented results better than some protease purifications.

Previous studies have shown that other metalloproteases exhibit variable molecular weights. For example, Bersanetti et al. (2005) isolated a 51.5-kDa metalloprotease from Serratia proteamaculans culture medium, and a $19-\mathrm{kDa}$ metalloprotease was produced by Penicillium spp. under solid-state fermentation (El-Gendy, 2010). Additionally, Termitomyces clypeatus (Majumder et al., 2015) and Bacillus sp TKU004 (Wang et al., 2006) produce metalloproteases with molecular masses similar to those of the enzyme secreted by E. javanicum in our study $(30 \mathrm{kDa})$.

\section{Biochemical Characterization Effects of pH and Temperature on Enzyme Activity}

Proteases have several properties that may facilitate their use in industrial applications, including optimal temperature, optimal $\mathrm{pH}$, specificity, activity, and stability (Mahajan and Badgujar, 2010). Similar to E. javanicum, many microorganisms are able to produce neutral proteases. For example, $P$. digitatum (Aissaoui et al., 2014), P. italicum (Abidi et al., 2014), Graphium putredinis, and Trichoderma harzianum (Savitha et al., 2011) produce serine proteases with an optimum $\mathrm{pH}$ at 7.0. Additionally, the metalloproteases from Microbacterium sp. (Thys and Brandelli, 2006), Penicillium spp. (El-Gendy, 2010), Thermoascus aurantiacus (Merheb-Dini et al., 2009), and Streptomyces septatus TH-2 (Hatanaka et al., 2005) produce enzymes with a neutral pH optimum.

Additionally, microorganisms are able to secrete enzymes that can function in wide temperature range. As previously reported, P. italicum (Abidi et al., 2014), P. chrysogenum (Chen et al., 2013), Botrytis cinerea (Abidi et al., 2011), Graphium putredinis, and Trichoderma harzianum (Savitha et al., 2011) produce proteases with an optimum temperature of $50^{\circ} \mathrm{C}$, whereas the serine protease from $P$. waksmanii (Graminho et al., 2013) exhibits maximum activity at $35^{\circ} \mathrm{C}$. A metalloprotease isolated from Thermoascus aurantiacus was found to have high proteolytic activity at $75^{\circ} \mathrm{C}$ (Merheb-Dini et al., 2009), and that from Termitomyces clypeatus was found to have high proteolytic activity at $45^{\circ} \mathrm{C}$ (Majumder et al., 2015).

The stability of enzymes at different $\mathrm{pH}$ values and temperatures also affects the applicability of the enzyme in industrial processes. Enzymes that are stable at a wide range of temperatures and $\mathrm{pH}$ values may have broad industrial applications. For example, proteases produced by $P$. italicum (Abidi et al., 2014) and Beauveria sp. (Shankar et al., 2011) exhibit high activity from $\mathrm{pH} 4.0-11.0$ and 3.0-11.0, respectively. In contrast, the protease produced by Botrytis cinerea is stable from pH 6.0-9.0 (Abidi et al., 2011). The metalloproteases from Penicillium spp. show stability in a lower $\mathrm{pH}$ range (6.0-8.0 and 6.0-11.0; El-Gendy, 2010). In our study, we found that the enzyme from E. javanicum was stable at a wide $\mathrm{pH}$ range. Moreover, the thermal stability of our enzyme was similar to that of proteases from $P$. italicum, which maintained about $80 \%$ activity at 40 and $50^{\circ} \mathrm{C}$ and $60 \%$ activity at $60^{\circ} \mathrm{C}$ after $60 \mathrm{~min}$ (Abidi et al., 2014). In contrast, the proteases from Boritrys cinerea maintained only $10 \%$ activity at $60^{\circ} \mathrm{C}$ after $60 \mathrm{~min}$ (Abidi et al., 2011), whereas the proteases from Graphium putredinis and Trichoderma harzianum were stable for only $15 \mathrm{~min}$ at $60^{\circ} \mathrm{C}$ (Savitha et al., 2011). A metalloprotease produced by Microbacterium sp showed similar behavior to that isolated from E. javanicum, maintaining more than $80 \%$ activity at 
TABLE 4 | Kinetic parameters for the hydrolysis by the E. javanicum protease of the peptide series derived from reference peptide Abz-KLRSSKQ-EDDnp modified at $P_{1}, P_{2}$, and $P_{3}$ positions.

\begin{tabular}{|c|c|c|c|}
\hline & $k_{\text {cat }}\left(s^{-1}\right)$ & $K_{\mathrm{M}}(\mathrm{mM})$ & $k_{\text {cat }} / K_{M}\left(\mathrm{mM}^{-1} \mathrm{~s}^{-1}\right)$ \\
\hline \multicolumn{4}{|l|}{$\mathrm{P}_{1}$ position } \\
\hline Abz-KLR $\downarrow 45 \% S \downarrow 55 \% S K Q-E D D n p$ & $27.9 \pm 0.2$ & $0.013 \pm 0.001$ & $2,146 \pm 167$ \\
\hline Abz-KLFSSKQ-EDDnp & $42.9 \pm 4.8$ & $0.021 \pm 0.005$ & $2,043 \pm 251$ \\
\hline Abz-KLMS $\downarrow S K Q-E D D n p$ & $12.9 \pm 0.4$ & $0.007 \pm 0.001$ & $1,843 \pm 242$ \\
\hline Abz-KLYS $\downarrow S K Q-E D D n p$ & $4.5 \pm 0.5$ & $0.010 \pm 0.003$ & $450 \pm 89$ \\
\hline Abz-KLHS $\downarrow S K Q-E D D n p$ & $3.3 \pm 0.2$ & $0.007 \pm 0.000$ & $471 \pm 24$ \\
\hline $\mathrm{Abz-KLA} \downarrow$ SSKQ-EDDnp & $6.9 \pm 2.2$ & $0.019 \pm 0.013$ & $363 \pm 178$ \\
\hline $\mathrm{Abz}-\mathrm{KL} \mathbf{Q} \downarrow S \downarrow S K Q-E D D n p$ & $1.5 \pm 0.0$ & $0.004 \pm 0.001$ & $375 \pm 51$ \\
\hline Abz-KLVS $\downarrow S K Q-E D D n p$ & $4.5 \pm 0.3$ & $0.021 \pm 0.005$ & $214 \pm 42$ \\
\hline \multicolumn{4}{|l|}{$\mathrm{P}_{2}$ position } \\
\hline Abz-KLR $\downarrow 45 \% S \downarrow 55 \% S K Q-E D D n p$ & $27.9 \pm 0.2$ & $0.013 \pm 0.001$ & $2,146 \pm 167$ \\
\hline Abz-KVRS $\downarrow S K Q-E D D n p$ & $36.4 \pm 0.3$ & $0.017 \pm 0.001$ & $2,141 \pm 93$ \\
\hline Abz-KRRS $\downarrow S K Q-E D D n p$ & $40.7 \pm 1.1$ & $0.022 \pm 0.001$ & $1,850 \pm 59$ \\
\hline Abz-KIR $\downarrow 50 \% S \downarrow 50 \% S K Q-E D D n p$ & $49.7 \pm 3.2$ & $0.029 \pm 0.003$ & $1,714 \pm 86$ \\
\hline Abz-KMRS $\downarrow S K Q-E D D n p$ & $35.6 \pm 0.5$ & $0.021 \pm 0.001$ & $1,695 \pm 37$ \\
\hline Abz-KYRS $\downarrow 50 \% S \downarrow 50 \% K Q-E D D n p$ & $42.7 \pm 3.2$ & $0.026 \pm 0.004$ & $1,642 \pm 350$ \\
\hline Abz-KKRS $\downarrow S K Q-E D D n p$ & $59.3 \pm 12.1$ & $0.039 \pm 0.008$ & $1,520 \pm 6$ \\
\hline Abz-KARS $\downarrow S K Q-E D D n p$ & $28.1 \pm 1.5$ & $0.032 \pm 0.003$ & $878 \pm 29$ \\
\hline Abz-KFR $\downarrow S S K Q-E D D n p$ & $8.1 \pm 0.7$ & $0.012 \pm 0.004$ & $675 \pm 193$ \\
\hline Abz-KPRS $\downarrow S K Q-E D D n p$ & $19.8 \pm 5.4$ & $0.033 \pm 0.015$ & $600 \pm 114$ \\
\hline Abz-KSRS $\downarrow S K Q-E D D n p$ & $10.7 \pm 1.4$ & $0.031 \pm 0.009$ & $345 \pm 63$ \\
\hline Abz-KERS $\downarrow S K Q-E D D n p$ & $4.3 \pm 1.0$ & $0.020 \pm 0.005$ & $215 \pm 6$ \\
\hline \multicolumn{4}{|l|}{$\mathrm{P}_{3}$ position } \\
\hline Abz-KLR $\downarrow 45 \% S \downarrow 55 \% S K Q-E D D n p$ & $27.9 \pm 0.2$ & $0.013 \pm 0.001$ & $2,146 \pm 167$ \\
\hline Abz-VLR $\downarrow 73 \% S \downarrow 27 \% S K Q-E D D n p$ & $45.39 \pm 0.66$ & $0.010 \pm 0.000$ & $4,539 \pm 28$ \\
\hline Abz-ILR $\downarrow 71 \% S \downarrow 29 \% S K Q-E D D n p$ & $42.75 \pm 4.12$ & $0.011 \pm 0.002$ & $3,886 \pm 353$ \\
\hline Abz-ALR $\downarrow S \downarrow S K Q-E D D n p$ & $36.87 \pm 1.69$ & $0.013 \pm 0.001$ & $2,836 \pm 133$ \\
\hline Abz-RLRSSKQ-EDDnp & $19.17 \pm 1.97$ & $0.013 \pm 0.001$ & $1,475 \pm 227$ \\
\hline 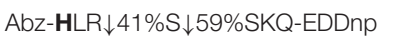 & $27.11 \pm 0.18$ & $0.021 \pm 0.001$ & $1,290 \pm 63$ \\
\hline Abz-GLR $\downarrow 41 \% S \downarrow 59 \% S K Q-E D D n p$ & $18.55 \pm 0.67$ & $0.015 \pm 0.001$ & $1,237 \pm 53$ \\
\hline 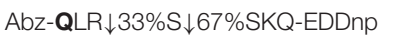 & $20.59 \pm 0.36$ & $0.019 \pm 0.001$ & $1,084 \pm 65$ \\
\hline Abz-YLR $\downarrow 39 \% S \downarrow 61 \% S K Q-E D D n p$ & $12.99 \pm 1.26$ & $0.014 \pm 0.002$ & $928 \pm 220$ \\
\hline Abz-FLR $\downarrow 44 \% S \downarrow 56 \% S K Q-E D D n p$ & $14.21 \pm 0.43$ & $0.018 \pm 0.004$ & $789 \pm 162$ \\
\hline Abz-SLRS $\downarrow S K Q-E D D n p$ & $10.32 \pm 0.49$ & $0.018 \pm 0.001$ & $573 \pm 19$ \\
\hline Abz-WLR $\downarrow 40 \% S \downarrow 60 \% S K Q-E D D n p$ & $4.38 \pm 1.74$ & $0.013 \pm 0.008$ & $337 \pm 68$ \\
\hline
\end{tabular}

The values were presented as media \pm standard deviation. The letter marked in bold refers the amino acids that were exchanged in each substrate.

$55^{\circ} \mathrm{C}$ and about $70 \%$ activity at $60^{\circ} \mathrm{C}$ after 60 min (Thys and Brandelli, 2006). Thus, the enzyme produced by E. javanicum was more stable than some proteases from thermophilic fungi. This resistance to high temperatures is interesting for industrial applications of the enzyme.

Some food processes use high temperatures to avoid the contamination with microorganisms. Proteases that act in high temperatures can be applied in meat tenderization, clean up of DNA before PCR (Bruins et al., 2001) and textile industry to remove gum (Srilakshmi et al., 2014).

\section{Effects of lons and Inhibitors}

Some proteases, particularly metalloproteases, may be influenced by the presence of metal ions. Therefore, researchers have evaluated the effects of ions on proteolytic activity. For example, the metalloprotease produced under solid-state fermentation by Bacillus sp. exhibits improved activity in the presence of sodium (Saxena and Singh, 2011). Additionally, proteases from P. waksmanii (Graminho et al., 2013) and Botrytis cinerea (Abidi et al., 2011) show increased activity in the presence of barium. We observed the same tendencies in the metalloprotease isolated in this study. Similarly, a protease from Beauveria sp. exhibits increased activity after pre-incubation with cobalt (Shankar et al., 2011). In contrast, the presence of aluminum decreases the activity of proteases from P. waksmanii (Graminho et al., 2013) and Aspergillus oryzae KSK-3 (Shirasaka et al., 2012). Finally, inhibitors, such as EDTA, can be used to classify the protease according to it catalytic site. EDTA is a metal chelating agent, and proteolytic activity of a metalloprotease is linked to presence of divalent metal ions, which can be directly related to the catalytic site or structure. In our study, EDTA inhibited the activity of our enzyme, whereas barium enhanced the activity of our enzyme, 
TABLE 5 | Kinetic parameters for the hydrolysis by the $E$. javanicum protease of the peptide series derived from reference peptide Abz-KLRSSKQ-EDDnp modified at $\mathrm{P}^{\prime}{ }_{1}, \mathrm{P}^{\prime}{ }_{2}$, and $\mathrm{P}^{\prime}{ }_{3}$ positions.

\begin{tabular}{|c|c|c|c|}
\hline & $k_{\text {cat }}\left(\mathbf{s}^{-1}\right)$ & $K_{\mathrm{M}}(\mathrm{mM})$ & $k_{\text {cat }} / K_{\mathrm{M}}\left(\mathrm{mM}^{-1} \mathrm{~s}^{-1}\right)$ \\
\hline \multicolumn{4}{|l|}{$\mathrm{P}^{\prime}{ }_{1}$ position } \\
\hline Abz-KLR $\downarrow 45 \% S \downarrow 55 \% S K Q-E D D n p$ & $27.9 \pm 0.2$ & $0.013 \pm 0.001$ & $2,146 \pm 167$ \\
\hline Abz-KLRY $\downarrow S K Q-E D D n p$ & $614.94 \pm 24.36$ & $0.007 \pm 0.001$ & $87,849 \pm 15571$ \\
\hline Abz-KL $\downarrow 49 \% R \mathbf{R} \downarrow 51 \% S K Q-E D D n p$ & $132.40 \pm 1.88$ & $0.007 \pm 0.001$ & $18,914 \pm 3736$ \\
\hline Abz-KLRK $\downarrow 46 \% S \downarrow 54 \% K Q-E D D n p$ & $119.01 \pm 4.05$ & $0.008 \pm 0.001$ & $14,876 \pm 1584$ \\
\hline Abz-KLRF $\downarrow S K Q-E D D n p$ & $71.95 \pm 6.04$ & $0.008 \pm 0.001$ & $8,994 \pm 891$ \\
\hline Abz-KLRH $\downarrow S K Q-E D D n p$ & $116.95 \pm 2.23$ & $0.016 \pm 0.002$ & $7,309 \pm 664$ \\
\hline Abz-KLRA $\downarrow S K Q-E D D n p$ & $141.87 \pm 19.61$ & $0.022 \pm 0.004$ & $6,449 \pm 146$ \\
\hline Abz-KL $\downarrow R \mathbf{V S K Q - E D D n p ~}$ & $63.32 \pm 3.46$ & $0.023 \pm 0.001$ & $2,753 \pm 22$ \\
\hline Abz-KL $\downarrow 46 \% R \mathbf{M} \downarrow 54 \% S K Q-E D D n p$ & $12.92 \pm 0.38$ & $0.007 \pm 0.001$ & $1,846 \pm 242$ \\
\hline Abz-KLRE $\downarrow S K Q-E D D n p$ & $44.79 \pm 0.32$ & $0.027 \pm 0.002$ & $1,659 \pm 134$ \\
\hline Abz-KLRP $\downarrow S K Q-E D D n p$ & $26.27 \pm 2.36$ & $0.019 \pm 0.002$ & $1,383 \pm 57$ \\
\hline Abz-KLRQ $\downarrow$ SKQ $Q-E D D n p$ & $14.30 \pm 0.59$ & $0.011 \pm 0.002$ & $1,300 \pm 212$ \\
\hline Abz-KLRG $\downarrow S K Q-E D D n p$ & $5.71 \pm 0.51$ & $0.017 \pm 0.000$ & $336 \pm 20$ \\
\hline \multicolumn{4}{|l|}{$\mathrm{P}_{2}^{\prime}$ position } \\
\hline Abz-KLR $\downarrow 45 \% S \downarrow 55 \% S K Q-E D D n p$ & $27.9 \pm 0.2$ & $0.013 \pm 0.001$ & $2,146 \pm 167$ \\
\hline 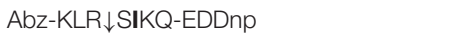 & $41.1 \pm 3.6$ & $0.003 \pm 0.001$ & $13,700 \pm 2538$ \\
\hline Abz-KLR $\downarrow 49 \% S \downarrow 51 \% \mathbf{R} K Q-E D D n p$ & $52.2 \pm 0.3$ & $0.005 \pm 0.000$ & $10,440 \pm 139$ \\
\hline 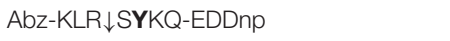 & $24.1 \pm 2.7$ & $0.003 \pm 0.000$ & $8,033 \pm 562$ \\
\hline 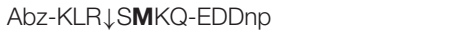 & $60.6 \pm 4.0$ & $0.007 \pm 0.001$ & $8,657 \pm 370$ \\
\hline Abz-KLR $\downarrow 21 \% S \downarrow 79 \% \mathbf{A K Q}-E D D n p$ & $54.9 \pm 2.2$ & $0.012 \pm 0.001$ & $4,575 \pm 250$ \\
\hline 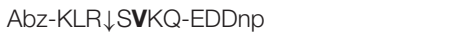 & $41.1 \pm 2.1$ & $0.010 \pm 0.001$ & $4,110 \pm 139$ \\
\hline Abz-KLR $\downarrow 38 \% S \downarrow 62 \% \mathbf{Q K Q}-E D D n p$ & $41.2 \pm 1.7$ & $0.011 \pm 0.001$ & $3,745 \pm 153$ \\
\hline 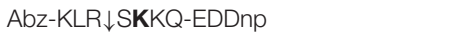 & $27.7 \pm 2.4$ & $0.011 \pm 0.002$ & $2,518 \pm 154$ \\
\hline $\mathrm{Abz}-\mathrm{KL} \downarrow R \downarrow \mathrm{R} \downarrow \mathbf{H} \downarrow K \mathrm{~K}-\mathrm{EDDnp}$ & $17.7 \pm 2.4$ & $0.009 \pm 0.001$ & $1,967 \pm 135$ \\
\hline Abz-KL $\downarrow 45 \% R \downarrow 55 \% S W K Q-E D D n p$ & $14.8 \pm 1.0$ & $0.013 \pm 0.002$ & $1,138 \pm 65$ \\
\hline Abz-KLR $\downarrow 58 \% S \downarrow 42 \% E K Q-E D D n p$ & $8.6 \pm 1.5$ & $0.010 \pm 0.004$ & $860 \pm 228$ \\
\hline Abz-KL $\downarrow 46 \% R \downarrow 54 \% S F K Q-E D D n p$ & $15.5 \pm 2.4$ & $0.018 \pm 0.004$ & $861 \pm 55$ \\
\hline $\mathrm{Abz}-\mathrm{KL} \downarrow R \downarrow \mathrm{R} \downarrow \mathbf{G K Q}-\mathrm{EDDnp}$ & $11.2 \pm 2.2$ & $0.022 \pm 0.006$ & $509 \pm 36$ \\
\hline Abz-KLR\SPKQ-EDDnp & $5.0 \pm 0.6$ & $0.026 \pm 0.005$ & $192 \pm 13$ \\
\hline \multicolumn{4}{|l|}{$\mathrm{P}_{3}^{\prime}$ position } \\
\hline Abz-KLR $\downarrow 45 \% S \downarrow 55 \% S K Q-E D D n p$ & $27.9 \pm 0.2$ & $0.013 \pm 0.001$ & $2,146 \pm 167$ \\
\hline Abz-KL $\downarrow 27 \% R \downarrow 20 \% S \downarrow 53 \% S Y Q-E D D n p$ & $23.0 \pm 0.6$ & $0.006 \pm 0.000$ & $3,833 \pm 101$ \\
\hline Abz-KLR $\downarrow 29 \% S \downarrow 71 \% S F Q-E D D n p$ & $27.1 \pm 1.2$ & $0.013 \pm 0.003$ & $2,085 \pm 451$ \\
\hline Abz-KLRS $\downarrow S I Q-E D D n p$ & $13.0 \pm 3.1$ & $0.008 \pm 0.000$ & $1,625 \pm 290$ \\
\hline Abz-KL $\downarrow 32 \% R \downarrow 18 \% S \downarrow 50 \% S V Q-E D D n p$ & $17.4 \pm 2.4$ & $0.019 \pm 0.003$ & $916 \pm 12$ \\
\hline 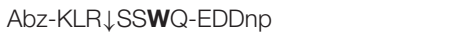 & $9.8 \pm 0.0$ & $0.014 \pm 0.000$ & $700 \pm 12$ \\
\hline Abz-KL $\downarrow 81 \% R \downarrow 19 \% S S A Q-E D D n p$ & $9.6 \pm 0.9$ & $0.026 \pm 0.003$ & $369 \pm 6$ \\
\hline $\mathrm{Abz}-\mathrm{KL} \downarrow \mathbb{R} \downarrow S \downarrow S S Q-E D D n p$ & $4.2 \pm 0.6$ & $0.018 \pm 0.007$ & $233 \pm 72$ \\
\hline
\end{tabular}

The values were presented as media \pm standard deviation. The letter marked in bold refers the amino acids that were exchanged in each substrate.

suggesting that the protease isolated from E. javanicum in this study was a metalloprotease.

\section{Effect of Surfactants}

In order to utilize proteases in the detergent industry, the enzymes must be highly active and stable at a high $\mathrm{pH}$ and temperature and must show compatibility with other chelating and oxidant agents added to the detergent (Rani et al., 2013). Detergents and surfactants may disrupt hydrophobic interactions within the protein structure and negatively or positively affect proteolytic activity. Enzymes produced by P. digitatum maintain about $64 \%$ activity in the presence of Tween (Aissaoui et al.,
2014). In contrast, enzymes produced by Myceliophthora sp. show increased activity in the presence of Tween (117\% of residual activity; Zanphorlin et al., 2011). In addition, the protease produced by $P$. waksmanii exhibits only $43 \%$ activity in the presence of this detergent (Graminho et al., 2013). The protease from $P$. digitatum exhibits about $70 \%$ residual activity in the presence of Triton (Aissaoui et al., 2014), whereas that from Thermoascus aurantiacus has no stability in the presence of the same surfactant (Merheb-Dini et al., 2009). Proteases produced by $P$. waksmanii have been shown to retain about $43 \%$ activity in the presence of $0.8 \%$ Triton (Graminho et al., 2013). Some proteases produced by P. waksmanii (Graminho et al., 2013) and 
Myceliophthora sp (Zanphorlin et al., 2011) have no activity when SDS is added to the solution, whereas the protease produced by Botrytis cinerea (Abidi et al., 2011) shows increased stability in the presence of $1 \%$ SDS.

\section{Effects of Urea, Guanidine, and DTT}

Reducing agents such as DTT may break disulfide bonds from sulfhydryl groups. The tertiary protein structure depends on these connections and hydrophobic interactions to stabilize the protein (Vieille and Zeikus, 2001). Indeed, disulfide bonds are important for the structure and proteolytic activity of the metalloprotease produced by E. javanicum. Additionally, the enzyme from Thermoascus aurantiacus also showed a decrease in activity as the concentration of DTT increased (Merheb-Dini et al., 2009). Additionally, the enzyme produced by P. waksmanii maintained only $15 \%$ activity in the presence of $20 \mathrm{mM}$ DTT (Graminho et al., 2013); thus, this enzyme was less stable than that produced by E. javanicum. Hydrogen bonds also help to maintain the high order structure of proteins. Chaotropic agents, such as urea and guanidine, can disrupt these connections and induce changes in protein conformation (Adrio and Demain, 2014), thereby affecting proteolytic activity, as was observed for the metalloprotease secreted by E. javanicum.

\section{Kinetic Experiments with a Synthetic Substrate}

In this study, we performed kinetic analysis to determine the specificity of the protease to certain substrates, which can be targets in industrial applications. Replacement of some amino acids at the $P_{1}$ and $P_{2}$ positions of the Abz-KLRSSKQ-EDDnp substrate blocked substrate cleavage, suggesting that the enzyme required specific amino acids at this position. Analysis of the amino acid residues at $\mathrm{P}_{3}$ position and the catalytic efficiency of the enzyme showed that there was a preference for non-polar amino acids. In contrast, all the amino acid residues allowed substrate cleavage at the $\mathrm{P}_{3}$ position; thus, there was lower enzymatic specificity at $\mathrm{P}_{3}$ compared with those at $\mathrm{P}_{1}$ and $\mathrm{P}_{2}$.

Replacement of amino acids at $\mathrm{P}^{\prime}{ }_{1}$ showed that polar amino acids positively influenced catalytic efficiency, with tyrosine having the greatest effects. At $\mathrm{P}^{\prime}{ }_{2}$, the subsite alternated between

\section{REFERENCES}

Abidi, F., Aissaoui, N., Chobert, J. M., Haertle, T., and Marzouki, M. N. (2014). Neutral serine protease from Penicillium italicum. Purification, biochemical characterization, and use for antioxidative Peptide preparation from Scorpaena notatamuscle. Appl. Biochem. Biotechnol. 174, 186-205. doi: 10.1007/s12010014-1052-6

Abidi, F., Chobert, J. M., Haertle, T., and Marzouki, M. N. (2011). Purification and biochemical characterization of stable alkaline protease Prot-2 from Botrytis cinerea. Process. Biochem. 46, 2301-2310. doi: 10.1016/j.procbio.2011.09.010

Adrio, J. L., and Demain, A. L. (2014). Microbial enzymes: tools for biotechnological processes. Biomolecules 4, 117-139. doi: 10.3390/biom4010117

Aissaoui, N., Abidi, F., Mahat, S., and Marzouki, M. N. (2014). Purification and biochemical characterization of a novel protease from Penicillium digitatum Use in bioactive peptides production. J. Basic Microbiol. 54, S178-S189. doi: 10.1002/jobm.201400179 polar and non-polar substrates; therefore, this position was nonspecific for the enzyme. Additionally, analysis of the kinetics at the $\mathrm{P}_{3}^{\prime}$ position showed that there was a preference for amino acids with an aromatic ring. Some amino acids also blocked cleavage completely, demonstrating that this position required specific amino acids. For positions at the "primed" side, the enzyme showed greater catalytic efficiency than when there were changes at the "unprimed" side positions. There were no similarities among the $\mathrm{P}_{1}, \mathrm{P}_{2}$, and $\mathrm{P}_{3}$ positions. Additionally, analysis of the specificity of proteases using FRET substrates showed that enzymes secreted by P. waksmanii (Graminho et al., 2013) and Myceliophthora sp. (Zanphorlin et al., 2011) showed the highest catalytic efficiency at the "unprimed" side, with Ile at $\mathrm{P}_{1}$ and Ile at $\mathrm{P}_{2}$, respectively. In contrast, proteases from Myceliophthora thermophila (Hamin Neto et al., 2015) and Aspergillus fumigatus (Da Silva et al., 2014) showed the highest catalytic efficiency at the "primed" side, with Ala at $\mathrm{P}_{2}^{\prime}$ and Leu at $\mathrm{P}_{3}^{\prime}$, respectively. Furthermore, different enzymes show specificity to the various types of substrates, highlighting the importance of kinetic assays.

In summary, the metalloprotease isolated from E. javanicum during solid-state fermentation exhibited characteristics that were important and desirable for a variety of industrial applications. These findings may provide important insights into the availability of novel enzyme resources for industrial processes; it is necessary studies in each industrial area to suggest an application.

\section{AUTHOR CONTRIBUTIONS}

Bioprocess, purification, biochemical characterization and kinetic experiment ( $\mathrm{YH}$ and $\mathrm{HC}$ ). Peptide substrate synthesis and cleavage site determination (LdO, JdO, MJ, and LJ). Determination the $\mathrm{N}$-terminal sequence (EA).

\section{FUNDING}

The authors would like to acknowledge financial support provided by Fundação de Amparo à Pesquisa do Estado de São Paulo (FAPESP; 2012/24703-8 and 2011/06986-0).

Berger, A., and Schechter, I. (1970). Mapping the active site of papain with the aid of peptide substrates and inhibitors. Philos. Trans. R. Soc. Lond. B Biol. Sci. 257, 249-264. doi: 10.1098/rstb.1970.0024

Bersanetti, P. A., Park, H. Y., Bae, K. S., Son, K. H., Shin, D. H., Hirata, I. Y., et al. (2005). Characterization of arazyme, an exocellular metalloprotease isolated from Serratia proteamaculans culture medium. Enzyme Microb. Technol. 37, 574-581. doi: 10.1016/j.enzmictec.2005.01.041

Bruins, M. E., Janssen, A. E. M., and Boom, R. M. (2001). Thermozymes and their applications a review of recent literature and patents. Appl. Biochem. Biotechnol. 90, 155-186. doi: 10.1385/ABAB:90:2:155

Chagas, J. R., Juliano, L., and Prado, E. S. (1991). Intramolecularly quenched fluorogenic tetrapeptide substrates for tissue and plasma kallikreins. Anal. Biochem. 192, 419-425. doi: 10.1016/0003-2697(91) 90558-B

Chen, Z., Ao, J., Yang, W., Jiao, L., Zheng, T., and Chen, X. (2013). Purification and characterization of a novel antifungal protein secreted by Penicillium 
chrysogenum from an Arctic sediment. Appl. Microbiol. Biotechnol. 97, 1038110390. doi: $10.1007 / \mathrm{s} 00253-013-4800-6$

Da Silva, R. R., Ângelo, T., and Cabral, H. (2013). Comparative evaluation of peptidases produced by Penicillium corylophilum and Penicillium waksmanii in solid-state fermentation using agro-industrial residues. J. Agric. Sci. Technol. B 3, 230-237.

Da Silva, R. R., Caetano, R. C., Okamotoc, D. N., De-Oliveira, L. C. G., Rosa, J. C., and Cabral, H. (2014). The identification and biochemical properties of the catalytic specificity of a serine peptidase secreted by Aspergillus fumigatus Fresenius. Protein Pept. Lett. 21, 663-671. doi: 10.2174/ 0929866521666140408114646

Dunn, B. M. (1989). "Determination of protease mechanism," in Proteolytic Enzymes: A Practical Approach, eds R. J. Beynon and J. S. Bond (Oxford: IRL Press), 57-81.

El-Gendy, M. M. A. (2010). Keratinase production by endophytic Penicillium spp. Morsy1 under solid-state fermentation using rice straw. Appl. Biochem. Biotechnol. 162, 780-794. doi: 10.1007/s12010-009$8802-\mathrm{x}$

Graminho, E. R., da Silva, R. R., de Freitas Cabral, T. P., Arantes, E. C., da Rosa, N. G., Juliano, L., et al. (2013). Purification, characterization, and specificity determination of a new serine protease secreted by Penicillium waksmanii. Appl. Biochem. Biotechnol. 169, 201-214. doi: 10.1007/s12010-0129974-3

Gupta, R., Beg, Q. K., Khan, S., and Chauhan, B. (2002). An overview on fermentation, downstream processing and properties of microbial alkaline proteases. Appl. Microbiol. Biotechnol. 60, 381-395. doi: 10.1007/s00253-002$1142-1$

Hamin Neto, Y. A. A., De Freitas, L. A. P., and Cabral, H. (2014). Multivariate analysis of the stability of spray-dried Eupenicillium javanicum peptidases. Dry. Technol. 32, 614-621. doi: 10.1080/07373937.2013. 853079

Hamin Neto, Y. A. A., de Souza Motta, C. M., and Cabral, H. (2013). Optimization of metalloprotease production by Eupenicillium javanicum in both solid-state and submerged bioprocesses. Afr. J. Biochem. Res. 7, 146-157.

Hamin Neto, Y. A. A., De-Oliveira, L. C. G., De-Oliveira, A. H. C., Rosa, J. C., Juliano, M. A., Juliano, L., et al. (2015). Determination of specificity and biochemical characteristics of neutral protease isolated from Myceliophthora thermophila. Protein Pept. Lett. 22, 972-982. doi: 10.2174/ 0929866522666150817093719

Hatanaka, T., Arima, J., Uesugi, Y., and Iwabuchi, M. (2005). Purification, characterization cloning, and sequencing of metalloendopeptidase from Streptomyces septatus TH-2. Arch. Bioquem. Biophys. 434, 289-298. doi: 10. 1016/j.abb.2004.11.018

Hirata, I., Sedenho Cezari, M., Nakaie, C., Boschcov, P., Ito, A., Juliano, M., et al. (1995). Internally quenched fluorogenic protease substrates: solidphase synthesis and fluorescence spectroscopy of peptides containing orthoaminobenzoyl/dinitrophenyl groups as donor-acceptor pairs. Lett. Pept. Sci. 1, 299-308. doi: 10.1007/BF00119771

Hmidet, N., Nawani, N., and Ghorbel, S. (2015). Recent development in production and biotechnological application of microbial enzymes. Biol. Med. Res. Int. 2015:280518.

Klemencic, I., Carmona, A. K., Cezari, M. H. S., Juliano, M. A., Juliano, L., Guncar, G., et al. (2000). Biochemical characterization of human cathepsin X revealed that the enzyme is an exopeptidase, acting as carboxymonopeptidase or carboxydipeptidase. Eur. J. Biochem. 267, 5404-5412. doi: 10.1046/j.14321327.2000.01592.x

Laemmli, U. K. (1970). Cleavage of structural proteins during the assembly of the head of bacteriophage T4. Nature 227, 680-685. doi: 10.1038/ 227680a0

Mahajan, R. T., and Badgujar, S. B. (2010). Biological aspects of proteolytic enzymes: a review. J. Pharm. Res. 3, 2048-2068.

Majumder, R., Banik, S. P., and Khowala, S. (2015). Purification and characterisation of $\kappa$-casein specific milk-clotting metalloprotease from Termitomyces clypeatus MTCC 5091. Food Chem. 173, 441-448. doi: 10.1016/ j.foodchem.2014.10.027

Merheb-Dini, C., Cabral, H., Leite, R. S. R., Zanphorlin, L. M., Okamoto, D. N., Bonilla Rodriguez, G. O., et al. (2009). Biochemical and functional characterization of ametalloprotease from the thermophilic fungus Thermoascus aurantiacus. J. Agric. Food Chem. 57, 9210-9217. doi: 10.1021/jf9017977

Nakadate, S., Nozawa, K., Horie, H., Fujii, Y., Nagai, M., Hosoe, T., et al. (2007). Eujavanicols A-C, decalin derivatives from Eupenicillium javanicum. J. Nat. Prod. 70, 1510-1512. doi: 10.1021/np078008a

Nakadate, S., Nozawa, K., Sato, H., Horie, H., Fujii, Y., Nagai, M., et al. (2008). Antifungal cyclic depsipeptide, eujavanicin a, isolated from Eupenicillium javanicum. J. Nat. Prod. 71, 1640-1642. doi: 10.1021/np800 2904

Nigam, P. S. (2013). Microbial enzymes with special characteristics for biotechnological applications. Biomolecules 3, 597-611. doi: 10.3390/ biom3030597

Oliveira, J. R., Bertolin, T. C., Andrade, D., Oliveira, L. C., Kondo, M. Y., Santos, J. Á, et al. (2015). Specificity studies on kallikrein related peptidase 7 (KLK7) and effects of osmolytes and glycosaminoglycans on its peptidase activity. Biochim. Biophys. Acta 1854, 73-83. doi: 10.1016/j.bbapap.2014. 10.018

Rani, K., Rana, R., and Datt, S. (2013). Review on latest overview of proteases. Int. J. Sci. Res. 3, 1-9.

Sarath, G., de la Motte, R. S., and Wagner, F. W. (1989). "Protease assay methods," in Proteolytic Enzymes: A Practical Approach, eds R. J. Beynon and J. S. Bond (Oxford: IRL Press), 25-56.

Sarrouh, B., Santos, T. M., Miyoshi, A., Dias, R., and Azevedo, V. (2012). Up-todate insight on industrial enzymes applications and global market. J. Bioprocess Biotechnol. S4:002.

Savitha, S., Sadhasivam, S., Swaminathan, K., and Lin, F. H. (2011). Fungal protease: production, purification and compatibility with laundry detergents and their wash performance. J. Taiwan Inst. Chem. Eng. 42, 298-304. doi: $10.1007 / \mathrm{s} 00253-009-2145-y$

Saxena, R., and Singh, R. (2011). Characterization of a metallo-protease produced in solid-state fermentation by a newly isolated Bacillus strain. Acta Biol. Szeged. $55,13-18$.

See, Y. S., and Jackowski, G. (1989). "Estimating molecular weights of polypeptides by SDS gel electrophoresis," in Protein Structure a Pratical Aprroach, ed. T. E. Creigton (New York: Oxford University Press), 1-19.

Shankar, S., Rao, M., and Laxman, R. S. (2011). Purification and characterization of an alkaline protease by a new strain of Beauveria sp. Process Biochem. 46, 579-585. doi: 10.1016/j.procbio.2010.10.013

Shirasaka, N., Naitou, M., Okamura, K., Kusuda, M., Fukuta, Y., and Terashita, T. (2012). Purification and characterization of a fibrinolytic protease from Aspergillus oryzae KSK-3. Mycoscience 53, 354-364. doi: 10.1007/S10267-0110179-3

Souza, P. M. D., Bittencourt, M. L. D. A., Caprara, C. C., Freitas, M. D., Almeida, R. P. C. D., Silveira, D., et al. (2015). A biotechnology perspective of fungal proteases. Braz. J. Microbiol. 46, 337-346. doi: 10.1590/S1517838246220140359

Srilakshmi, J., Madhavi, J., and Ammani, K. (2014). Commercial potential of fungal protease: past, present and future prospects. Int. J. Pharm. Chem. Biol. Sci. 2, 218-234.

Tao, N. G., Shi, W. Q., Liu, Y. J., and Huang, S. R. (2011). Production of feed enzymes from citrus processing waste by solid-state fermentation with Eupenicillium javanicum. Int. J. Food Sci. Technol. 46, 1073-1079. doi: 10.1111/ j.1365-2621.2011.02587.x

Thomas, L., Larroche, C., and Pandey, A. (2013). Current developments in solidstate fermentation. Biochem. Eng. J. 81, 146-161. doi: 10.1016/j.bej.2013.10. 013

Thys, R. C. S., and Brandelli, A. (2006). Purification and properties of a keratinolytic metalloprotease from Microbacterium sp. J. Appl. Microbiol. 101, 1259-1268. doi: 10.1111/j.1365-2672.2006.03050.x

Vieille, C., and Zeikus, G. J. (2001). Hyperthermophilic enzymes: sources, uses, and molecular mechanisms for thermostability. Microbiol. Mol. Biol. Rev. 65, 1-43. doi: 10.1128/MMBR.65.1.1-43.2001

Wang, S.-L., Kao, T.-Y., Wang, C.-L., Yen, Y.-H., Chern, M.-K., and Chen, Y.-H. (2006). A solvent sTable metalloprotease produced by Bacillus sp TKU004 and its application in the deproteinization of squid pen for beta-chitin preparation. Enzyme Microb. Technol. 39, 724-731. doi: 10.1016/j.enzmictec.2005. 12.007 
Zanphorlin, L. M., Cabral, H., Arantes, E., Assis, D., Juliano, L., Juliano, M. A., et al. (2011). Purification and characterization of a new alkaline serine protease from the thermophilic fungus Myceliophthora sp. Process Biochem. 46, 2137-2143. doi: 10.1016/j.procbio.2011.08.014

Conflict of Interest Statement: The authors declare that the research was conducted in the absence of any commercial or financial relationships that could be construed as a potential conflict of interest.
Copyright (C) 2017 Hamin Neto, de Oliveira, de Oliveira, Juliano, Juliano, Arantes and Cabral. This is an open-access article distributed under the terms of the Creative Commons Attribution License (CC BY). The use, distribution or reproduction in other forums is permitted, provided the original author(s) or licensor are credited and that the original publication in this journal is cited, in accordance with accepted academic practice. No use, distribution or reproduction is permitted which does not comply with these terms. 